\title{
The Scavenger Receptor CD68 Regulates Platelet Mediated Oxidized Low-Density Lipoprotein (oxLDL) Deposition in Atherosclerotic Vessels at an Early Stage of Atherosclerosis in LDLR//ApoBec/- Mice
}

\author{
Stephan Zeibiga ${ }^{\mathrm{a}}$ Manuela Büttcher ${ }^{\mathrm{b}}$ Silvia Goebel ${ }^{\mathrm{a}}$ Jessica Paulia \\ Annique Hunger ${ }^{\mathrm{a}} \quad$ Martin Ungerer $^{\mathrm{a}} \quad$ Meinrad Gawaz $^{\mathrm{b}}$ Götz Münch ${ }^{\mathrm{a}}$ \\ ${ }^{a}$ AdvanceCOR, Martinsried, Germany, bDepartment for Cardiology and Vascular Diseases, University of \\ Tübingen, Tübingen, Germany
}

\section{Key Words}

Oxidized low-density lipoprotein (oxLDL) • Platelets • Atherosclerosis • CD68

\begin{abstract}
Background/Aims: Oxidative modifications of low-density lipoprotein (ox-LDL) play a key role in initial steps of atheroprogression possibly via specific scavenger receptors on inflammatory and endothelial cells. Amongst others, CD68 might play a crucial role in this leading to fatty streak formation. Methods: Different CD68-Fc fusion proteins were cloned, expressed and tested in vitro for their oxLDL binding properties as a decoy for endogenous oxLDL. Physiological functions were tested in foam cell assays with human monocytes in culture and by binding oxLDL from human blood. The best suited candidate FclgG2-FL-CD68 was injected twice weekly in $L D L$ receptor and ApoBec deficient mice $\left(L D L R^{-1 /} /\right.$ Apobec $\left.^{-1}\right)$, and the oxLDL content was measured in peripheral blood, in different cell types of the spleen and aortic wall by specific oxLDL antibodies using flow cytometry. Results: Different variants of the CD68-FC bound to copper-oxided LDL (oxLDL), LDL and to a lesser extent HDL with different efficacy in an ELISA based binding assay in vitro. Native oxLDL content in human blood derived from patients with extended atherosclerosis was reduced after passage through a specific protein G column conjugated with the different CD68-Fc fusion proteins. Foam cell formation from human peripheral blood monocyte-platelet co-culture was reduced by the most effective CD68-Fc fusion proteins. oxLDL was not increased in the blood but markedly increased in the vessel wall from $L D L R^{-1} /$ Apobec $^{-1}$ mice at an early stage of atherosclerosis. Platelet-like cells in the vessel wall contributed most to the increase in tissue oxLDL. FclgG2-FL-CD68, reduced oxLDL content of aortic vessel wall cells from $L D L R^{-1} /$ Apobec $^{-1}$ mice. However a tissue specific reduction on the oxLDL content in peripheral blood, the spleen or cells from the aortic vessel




\section{Cellular Physiology Cell Physiol Biochem 2019;52;681-695

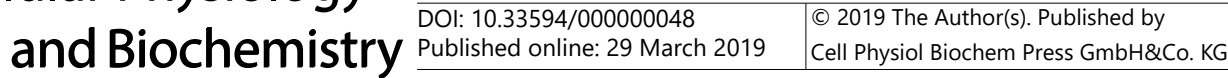 \\ Zeibig et al.: Platelet-Bound oxLDL Triggers Early Atherosclerosis}

by FclgG2-FL-CD68 could not be shown. Conclusion: Platelets contribute to increased tissue oxLDL in the aortic wall but not in peripheral blood. CD68 seems to play a role in the oxLDL metabolism in the vessel wall at early stages of atherosclerosis. FclgG2-FL-CD68 could serve as a novel therapeutic option to modify the oxLDL content in the vessel wall.

(C) 2019 The Author(s). Published by Cell Physiol Biochem Press GmbH\&Co. KG

\section{Introduction}

Atherosclerosis leading to thrombo-ischemic complications is one of the major causes of death in the western world. Lipoproteins, such as the low-density lipoprotein (LDL) play a prominent role in the induction and progression of atherosclerotic plaques in the vessel wall. Especially, foam cell formation in the vascular wall from tissue-specific monocytes and macrophages is crucial and the regulatory step of plaque formation. One of the main triggers for macrophage chemotaxis to the vessel wall is the modified, oxidized LDL (oxLDL). oxLDL is highly immunogenic, reduces the self-tolerance of the immune system and induces autoimmunological reactions urging inflammation in the vascular wall [1]. Due to presence of a wide range of anti-oxidants in plasma, LDL if oxidized in circulation is rather short-lived or is rapidly cleared off by the reticuloendothelial system. Most of oxLDL deposition therefore takes place in the sub-endothelial space of the vessel wall where it could be therapeutically targeted to prevent atherosclerosis. oxLDL deposited in vessels reduces motility and recruits tissue monocytes to the arterial intima, where they become resident to the vessel wall tissue. Differentiation into foam cells is triggered by oxLDL-uptake in monocytes or macrophages and constitutes one of the major steps in the development of atherosclerotic plaques. Platelets function as compartmentalized vehicles for lipids in the circulation, modify lipids through oxidative and metabolic processes and are poised as effective delivery system for these atherogenic lipids at the site of vascular disintegration or inflammation [2]. On the other hand phagocytic uptake of lipid loaded apoptotic platelets by monocytes and M1-M2 macrophages facilitate their differentiation into foam cells in vitro [3].

oxLDL uptake into macrophages functions via different scavenger receptors. SR-A, SRB1, LOX-1, CD36 and CD68 are relatively specific for oxLDL [4] and the latter is expressed mainly in macrophages [5]. Therefore, we wanted to assess whether the CD68 scavenger receptor, a 94 - 97- $\mathrm{kDa}$ oxLDL binding receptor which belongs to the type I transmembrane proteins, influences oxLDL levels in vivo. We characterized the therapeutic potential of a soluble form of CD68 as Fc fusion protein to check atheroprogression by sequestering circulatory (plasma) and vessel wall associated oxidized lipids. The hypothesis is that the specific binding and possibly reduction of oxLDL levels will have positive effects on foam cell formation thus reducing the major trigger for atherosclerotic plaque formation.

A comparable and promising approach is anti-oxLDL antibodies to bind and neutralize oxLDL. Different antibodies against oxLDL have been developed and atherosclerosis could be improved in vivo e.g. in LDL receptor -/- mice [6] and Apobec and LDL receptor -/- mice [7]. We have previously shown that a recombinant CD68-IgG-Fc fusion protein reduces atheroprogression and plaque rupture and instability in advanced atherosclerosis in ApoE -/- mice [8]. We are now testing further modifications of soluble recombinant CD68-Fc fusion proteins, consisting of the fragment crystalisable form of different human IgGs (FcIgG2 or FcIgG1), and the extracellular domain of human CD68. After in vitro characterization, the most suitable CD68-Fc fusion construct was assessed in vivo in a very early phase of atherosclerosis in $L D L R^{-\%} /$ Apobec $^{\%}$ mice. Our previous studies indicated that CD68 effects might be particularly important in the early phase of atherosclerosis [8]. 


\section{Cellular Physiology Cell Physiol Biochem 2019;52;681-695 \begin{tabular}{ll|l|l|l} 
DOl: 10.33594/000000048 & O 2019 The Author(s). Published by \\
\hline
\end{tabular} and BiOChemistry Published online: 29 March 2019 Cell Physiol Biochem Press GmbH\&Co. KG \\ Zeibig et al.: Platelet-Bound oxLDL Triggers Early Atherosclerosis}

\section{Materials and Methods}

\section{Cloning of FCIgG2-FL-CD68 and FC}

Different fusion proteins containing the fragment crystalisable (Fc) of human IgG and the extracellular domain of human CD68 were designed. Different linker sequences between these two domains were inserted to provide some structural flexibility to the protein. The DNA sequence was optimized for expression in Chinese Hamster Ovary (CHO) cells using the Geneart's GeneOprimizer ${ }^{\mathrm{R}}$ Software. The resulting sequence was commercially synthesized by GENEART AG (Regensburg, Germany) and cloned into the pcDNA5/FRT expression plasmid (Invitrogen $\mathrm{GmbH}$, Karlsruhe, Germany) via the BamHI and NhEI restriction sites. The pcDNA5/FRT allows gene expression under the SV40 early promoter and is suitable for the generation of stably expressing cell lines using the Invitrogen Flp- $\mathrm{In}^{\mathrm{TM}}$ system.

\section{Cell culture and protein expression}

After transfecting the Flp-In expression plasmid in Flp-In CHO cells, the cells were selected for stable expression by cultivating them in Ham's F12 Medium with stable glutamine (Biochrom AG, Berlin, Germany), 10\% FCS, $100 \mu \mathrm{g} / \mathrm{ml}$ Penicillin, $100 \mu \mathrm{g} / \mathrm{ml}$ Streptomycin (P/S) and $600 \mu \mathrm{g} / \mathrm{ml}$ Hygromycin-B as a selection antibiotic. For protein production in larger amounts, stably expressing CHO cells were subjected to suspension cell culture using a chemically defined, serum-free culture medium (ProCHO4, Lonza). Cells were passaged every 3-4 days with a dilution ratio of 1:4-1:5. Cell density was kept between $5 \times 10^{4}$ and 1 x $10^{6}$ cells $/ \mathrm{ml}$. Culture supernatant was collected and used for protein purification. Culture supernatants were collected after expression time and centrifuged at $1500 \mathrm{xg}$ for $5 \mathrm{~min}$ and filtered $(0.22 \mu \mathrm{g})$ to remove floating cells and cell debris. Supernatants were subjected for protein purification afterwards.

\section{Protein purification}

Recombinant protein was purified via affinity purification with protein G. Supernatants were loaded on a protein G HP $1 \mathrm{ml}$ affinity column (GE Healthcare, cat. No. 17-0405-03) at $1 \mathrm{ml} / \mathrm{min}$ flow rate. Columns were equilibrated with binding buffer ( $20 \mathrm{mM}$ sodium phosphate $\mathrm{pH} 7.0$ ) prior loading. The columns were washed with at least 20 column volumes of binding buffer to remove residual serum proteins from the culture medium. Bound recombinant protein was eluted from the column with low $\mathrm{pH}(0.1 \mathrm{M} \mathrm{Glycine} / \mathrm{HCl}$ $\mathrm{pH} 2.7$ ) and $0.5 \mathrm{ml}$ fractions were collected. Elution fractions were neutralized immediately by addition of $1 / 10^{\text {th }}$ volume of neutralization buffer $(1 \mathrm{M}$ Tris/ $\mathrm{HCl} \mathrm{pH} 9.0)$. After identification of the peak fractions by $\mathrm{OD}_{280}$ measurement, they were pooled and dialyzed against PBS afterwards at $4^{\circ} \mathrm{C}$. Protein concentration was determined after dialysis using the Pierce BCA assay according to the manufacturer's instructions. Protein samples were stored at $-20^{\circ} \mathrm{C}$ until use.

\section{Protein analysis}

Quality of the purification samples was analyzed by SDS polyacrylamide gel analysis with subsequent Coomassie Brilliant Blue staining and Western-Blotting with anti-human-Fc and anti CD68 antibodies. Coomassie staining was performed according to standard procedures using a $4 \%$ to $20 \%$ PAA gradient gel (LongLifeGels, NuSep). For Western-Blot analysis, proteins were blotted on a nitrocellulose membrane (Amersham) after SDS-PAGE (wet-blotting technique). Membrane was blocked with $3 \%$ milk powder in PBS + $0.1 \%$ Tween-20 (PBS-T). Antibody binding: Anti human Fc POD-coupled (Dianova), 1:5000 in $3 \%$ milk powder in PBS-T, incubation $1 \mathrm{~h}$ at RT. Membrane was developed with the Pierce West Pico ECL substrate according to the shipped protocol.

\section{oxLDL ELISA with coated oxLDL lipoprotein}

Nunc maxisorp 96-well plates were coated either with a dilution series of oxLDL (Sanbio, 3 - 0, 004 $\mu \mathrm{g} /$ well), or with a fixed concentration of oxLDL, LDL and HDL ( $1 \mu \mathrm{g} /$ well) in carbonate coating buffer. ELISA plates were incubated over night at $4^{\circ} \mathrm{C}$. Afterwards, plates were washed thrice with $200 \mu \mathrm{l}$ PBS per well and blocked using 3\% milk powder in PBS for $1 \mathrm{~h}$ at RT (200 $\mu \mathrm{l}$ per well). Depending on the coating (dilution series or fixed concentration) either a dilution series $(30-0,04 \mu \mathrm{g} / \mathrm{ml})$ or a fixed concentration $(10 \mu \mathrm{g} / \mathrm{ml})$ of the various Fc-CD68 receptor constructs in the soluble phase were compared in binding to the immobilized lipoproteins to the ELISA plates. PBS + 0.3\% FCS served as binding buffer. CD68-Fc proteins were incubated for $2 \mathrm{~h}$ at RT on the ELISA plate. Plates were washed thrice afterwards with $200 \mu \mathrm{l}$ PBS-T. 


\section{Cellular Physiology Cell Physiol Biochem 2019;52;681-695

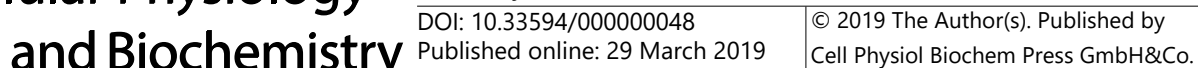 \\ Zeibig et al.: Platelet-Bound oxLDL Triggers Early Atherosclerosis}

Secondary anti human-Fc POD-coupled antibody (Dianova, \#109-035-088) was used in a 1:5000 dilution and $200 \mu \mathrm{l}$ were incubated for $1 \mathrm{~h}$ at RT per well. After finally washing ( $3 \mathrm{x}$ with $200 \mu \mathrm{l}$ PBS), the Pierce TMBsubstrate was used for detection according to the manufacturer's protocol. Plate was read in a Tecan Infinite 2000 ELISA reader.

\section{oxLDL ELISA with immobilized Fc-fusion proteins}

Nunc maxisorp ${ }^{R}$ 96-well plates were coated with a dilution series of purified recombinant protein (3$0.004 \mu \mathrm{g} /$ well) in $200 \mu \mathrm{l}$ carbonate coating buffer $\left(20 \mathrm{mM} \mathrm{H}_{2} \mathrm{CO}_{3}, \mathrm{pH} 9.6\right)$, over night at $4^{\circ} \mathrm{C}$. Plates were washed thrice with $200 \mu \mathrm{l} /$ well PBS after coating and blocked with 3\% milk powder in PBS (200 $\mu \mathrm{l} /$ well). A solution of $10 \mu \mathrm{g} / \mathrm{ml}$ oxLDL in PBS + 3\% BSA (100 $\mu \mathrm{l} /$ well) was incubated for $2 \mathrm{~h}$ at RT in the ELISA plate and washed thrice with $200 \mu \mathrm{l} /$ well PBS to remove unbound protein. A rabbit anti oxLDL antibody (biorbyt, \# orb10973, 1: 500 in PBS + 3\% milk powder) was used to detect oxLDL bound to the immobilized protein. A donkey anti rabbit POD-labeled secondary antibody (Jackson ImmunoResearch, \#711-035-152), 1:5000 in PBS $+3 \%$ BSA) was used for detection. After finally washing ( $3 \mathrm{x}$ with $200 \mu \mathrm{l} \mathrm{PBS}$ ), the Pierce TMB-substrate was used for detection according to the manufacturers protocol. Plate was read in a Tecan Infinite 2000 ELISA reader and data was analyzed using Microsoft Excel 2007 software.

oxLDL concentration measurement in patient blood samples and from $\mathrm{LDLR}^{-/-}$and Apobec ${ }^{-/}$mice

Human serum was taken from patients $(n=6)$ with generalized atherosclerosis and severe coronary artery disease with suspected elevated levels of serum oxLDL compared to the average population. Patients were screened during the COR-1 study (EudraCT 2010-022579-68) and serum sampling was approved by the ethics committee of the University of Würzburg, Germany. OxLDL content of the serum samples was measured using the ox-LDL/MDA Addukt ELISA kit (Immundiagnostik, \#k 7810) or ELISA Kit for oxLDL for mice (cloud-clone Corp, Caty, Tx, USA) according to manufacturer's protocol.

\section{Pull-Down experiments with protein G-immobilized fusion proteins}

Fc-CD68 proteins were immobilized to protein G Sepharose ${ }^{\mathrm{TM}} 4$ Fast FLOW Beads (GE Healthcare \#17-0618-05) to obtain an affinity resin for oxLDL. Therefore, $100 \mu \mathrm{l}$ beads slurry was transferred into an empty centrifuge column (Pierce ${ }^{\circledR}$ Centrifuge Columns $0.8 \mathrm{ml}$ ), which previously was equilibrated with $20 \mathrm{mM}$ phosphate buffer by washing $5 \mathrm{x}$ with $200 \mu \mathrm{l}$ per wash. Column was centrifuged for $2 \mathrm{~min}$ at $3000 \mathrm{~g}$ between washing steps to remove washing buffer. For immobilization, $10 \mu \mathrm{g}$ of the fusion proteins and an equimolar amount $(3 \mu \mathrm{g})$ of the FcIgG2 control protein, respectively, were incubated with the beads in a total volume of $100 \mu \mathrm{l} 20 \mathrm{mM}$ phosphate buffer for $30 \mathrm{~min}$ at RT with gentle shaking to avoid sedimentation. Buffer was exchanged after binding against $1 \mathrm{x}$ washing buffer taken from the ox-LDL/MDA Addukt ELISA kit. Afterwards, $100 \mu \mathrm{l}$ of human blood serum, diluted in a ratio of 1:5 with 1x oxLDL kit washing buffer, was loaded on the columns and incubated for $2 \mathrm{~h}$ at RT with constant shaking to allow binding of serum oxLDL to the immobilized proteins. Spin columns were centrifuged after incubation and the oxLDL-content of the flow through (blood after passage to CD68 bound to protein G column) was determined.

\section{Foam cell generation and foam cell quantification}

For monocyte preparation, $100 \mathrm{ml}$ of fresh human blood was mixed with $100 \mathrm{ml}$ of $1 \mathrm{x}$ PBS and the resulting dilution was overlaid over a Biocoll cussion in $50 \mathrm{ml}$ flacon tubes ( 6 tubes, $15 \mathrm{ml}$ Biocoll $+35 \mathrm{ml}$ diluted blood each). Tubes were centrifuged at $600 \mathrm{x}$ g for $15 \mathrm{~min}$ w/o break and the intermediate layer at top of the Biocoll cussion (containing primarily lymphocytes and monocytes) was harvested using a sterile Pasteur pipette. Cells were washed twice with $50 \mathrm{ml}$ PBS and transferred afterwards into $10 \mathrm{~cm}$ cell culture dishes containing $15 \mathrm{ml}$ of VLE RPMI 1640 medium $+10 \% \mathrm{FCS}$. P/S. Plates were incubated at $37^{\circ} \mathrm{C} / 5 \% \mathrm{CO}_{2}$ $\mathrm{o} / \mathrm{n}$ to allow mononuclear cells adhere to the surface. On the next day, cells were detached from the plate by treatment with $3 \mathrm{ml}$ Versene for $15 \mathrm{~min}$ on ice, washed and $5 \times 10^{4}$ cells were transferred into a 96-well cell culture microplate in $150 \mu \mathrm{l}$ of IMDM medium $+10 \% \mathrm{FCS}+\mathrm{P} / \mathrm{S}+1 \% \mathrm{MEM}$ non essential amino acids and $1 \%$ non-essential vitamins.

For thrombocyte preparation, $60 \mu \mathrm{l}$ of human blood were centrifuged at $200 \mathrm{~g}$ for $20 \mathrm{~min}$. Totally 45 $\mathrm{ml}$ platelet-rich plasma (centrifuge supernatant) were transferred into three $50 \mathrm{ml}$ falcon tubes and mixed with $35 \mathrm{ml}$ of Tyrodes buffer $\left(140 \mathrm{mM} \mathrm{NaCl}, 12 \mathrm{mM} \mathrm{NaHCO}_{3}, 2.6 \mathrm{mM} \mathrm{KCl}, 0.1 \%\right.$ glucose, $0.1 \%$ BSA, pH 6.5 or 7.4) pH 6.5. Thrombocytes were centrifuged at $900 \mathrm{~g}$ for $10 \mathrm{~min}$, supernatant was removed and pellets 


\section{Cellular Physiology Cell Physiol Biochem 2019;52;681-695 \\ \begin{tabular}{c|c|c|c|c|} 
DOI: 10.33594/000000048 & O 2019 The Author(s). Published by \\
and Biochemistry
\end{tabular} \\ \begin{tabular}{l|l} 
Published online: 29 March 2019 Cell Physiol Biochem Press GmbH\&Co. KG \\
\hline
\end{tabular} \\ Zeibig et al.: Platelet-Bound oxLDL Triggers Early Atherosclerosis}

were resuspended in Tyrodes buffer. A total amount of $1.6 \times 10^{7}$ cells were added to monocytes in coculture. Proteins to be tested were added to a final concentration of 50 and $100 \mu \mathrm{g} / \mathrm{ml}$. Simvastatin served as a positive control for the inhibition of foam cell formation and was used at final assay concentrations of $10,0.1$ and $0.01 \mu \mathrm{g} / \mathrm{ml}$. Co-culture of platelets and monocytes were incubated for 5 to 8 days until clear differentiation of monocytes to foam cells was visible under the microscope. Differentiated foam cells were counted microscopically in the whole cell culture dish.

Intracellular oxLDL status in peripheral blood, splenic cells and in aortic tissue

Peripheral blood was drawn from the retro orbital plexus of mice in ACD (12.5 $\mathrm{g} \mathrm{Na}_{3}$-Citrate, 6.82 g citric acid, $10 \mathrm{~g}$ glucose, ad $500 \mathrm{ml} \mathrm{H}_{2} \mathrm{O}$ )anticoagulant 1:4 v/v. Spleens were isolated from mice and homogenized by passing through a $40 \mu \mathrm{m}$ pore sieve and repeated pipetting, loaded onto a Ficoll gradient and subjected to differential centrifugation to isolate the PBMCs. Erythrocytes were lysed and the remaining cells were re-suspended in complete medium RPMI 1640 +10\%FCS (Gibco) +1\%Pen/Strep (Sigma-Aldrich) and cultured overnight. The descending aorta was dissected and homogenized with $450 \mathrm{U} / \mathrm{ml}$ Collagenase I, 250U/ml Collagenase XI, 120U/ml Hyaluronidase I, 120U/ml DNase 1 in HBSS supplemented with $+\mathrm{Ca}$, $+\mathrm{Mg}$. at $37^{\circ} \mathrm{C}$ for $50-60 \mathrm{mins}$ with constant stiring at 150 r.p.m. Samples were filtered $(70 \mu \mathrm{m}$ pore), and washed twice in PBS. All cells were fixed with PFA (1\% final concentration) for 20 mins at RT, permeabilized with $0.3 \%$ trion-X-100 for 10 min at RT and then washed once with $3 \mathrm{ml}$ of PBS and re-suspended. Cells were incubated with anti-human/mouse anti-OxLDL-FITC rabbit polyclonal antibody (Biorbyt) in combination with platelet markers (anti-mouse CD42b Dylight 649 antibody, Emfret Analytics) monocyte marker (antimouse CD14-APC, R\&D System) or macrophage (F4/80-APC Biolegend) marker for a further 30 min in the dark at RT. Finally, $300 \mu \mathrm{l}$ of PBS was added and samples were analyzed by flow cytometry (FACS-Calibur BD Biosciences). Basal cytometer settings for each channel were set according to the respective isotype controls i.e. gating was set above the threshold of the background fluorescence and used for specific fluorescence of the respective antibody. Data (height of the fluorescence event peaks) were collected in logarithmic mode and further analyzed using Microsoft Excel 2007.

\section{Animals}

Low density lipoprotein receptor and apolipoprotein B double knock-out mice with BlackSix background (LDLR $\%$ / Apobec ${ }^{-/}$mice Charles River) were used with BlackSix(C57BL/6J, Charles River) wild type as a control. No special diet was administered to the animals.

\section{Animal protocol for drug treatment}

12-20 week old $\mathrm{LDLR}^{-/} / \mathrm{Apobec}^{-/-}$mice were separated into two groups, the first group was treated with $10 \mathrm{mg} / \mathrm{kg}$ FcIgG2-FL-CD68 and the second with $3.3 \mathrm{mg} / \mathrm{kg}$ FcIgG2 (control group). Drug was applied intra peritoneal twice a week for 4 weeks by injection and full blood samples for FACS analysis were taken by venipuncture once a week and analyzed immediately. BlackSix mice were used as wild type controls. All animals and procedures were treated and performed according to the Bavarian animal ethical project $\mathrm{Nr}$. 55.2-1-54-2532.0-32-15 for the duration of four weeks. Mice were sacrificed after the end of the therapy.

\section{Oilred $O$ staining of mouse vessels}

The Aorta was dissected, cleaned from surrounding connective tissue and stored in PBS on ice and fixed in formalin for $24 \mathrm{~h}$. The blood vessels were transferred to Ethanol for $3 \mathrm{~min}$ and then stained with oil red o staining solution (3\% oil red o in $40 \%$ isopropanol/water) for $8 \mathrm{~min}$ and washed with tap water. Images were taken with a Zeiss Axiovert 200 microscope using a 2.5 x lens.

\section{Data analysis and Statistics}

Standard errors of means (SEM) values were calculated and are shown in the appropriate data representations. For data comparison, one way ANOVA with Tukey Post-hoc tests for multiple comparisons were performed and data were considered significant if $\mathrm{P} \leq 0.05$ and highly significant if $\mathrm{P} \leq 0.005$. 


\begin{tabular}{|c|c|c|}
\hline \multirow{2}{*}{$\begin{array}{l}\text { Cellular Physiology } \\
\text { and Biochemistry }\end{array}$} & \multicolumn{2}{|c|}{ Cell Physiol Biochem 2019;52;681-695 } \\
\hline & $\begin{array}{l}\text { DOl: 10.33594/0000000048 } \\
\text { Published online: } 29 \text { March } 2019\end{array}$ & $\begin{array}{l}\text { O } 2019 \text { The Author(s). Published by } \\
\text { Cell Physiol Biochem Press GmbH\&Co. KG }\end{array}$ \\
\hline
\end{tabular}

\section{Results}

Protein expression and purification: Fc-CD68-fusion proteins are available in high purity

Different variants of Fc-CD68-fusion proteins were provided as soluble receptors using Fc-IgG isotypes fused with the CD68 extracellular domain via variable linker sequences. An appropriate FcIgG2-control protein without the functional CD68-EC domain was expressed and purified as well (see Fig. 1a). All proteins were purified using protein G affinity chromatography in a single step reaching $>95 \%$ purity. A Coomassie-stained SDS-gel displayed a protein band with an apparent molecular mass of $\sim 110 \mathrm{kDa}$, which is much larger than the calculated mass of the peptide-chain, indicating the presence of major glycosylation of the protein (Fig. 1b, top). Identity of the recombinant protein was validated by WesternBlotting, with anti-human IgG and anti CD68 antibodies (Fig. 1b lower panel).

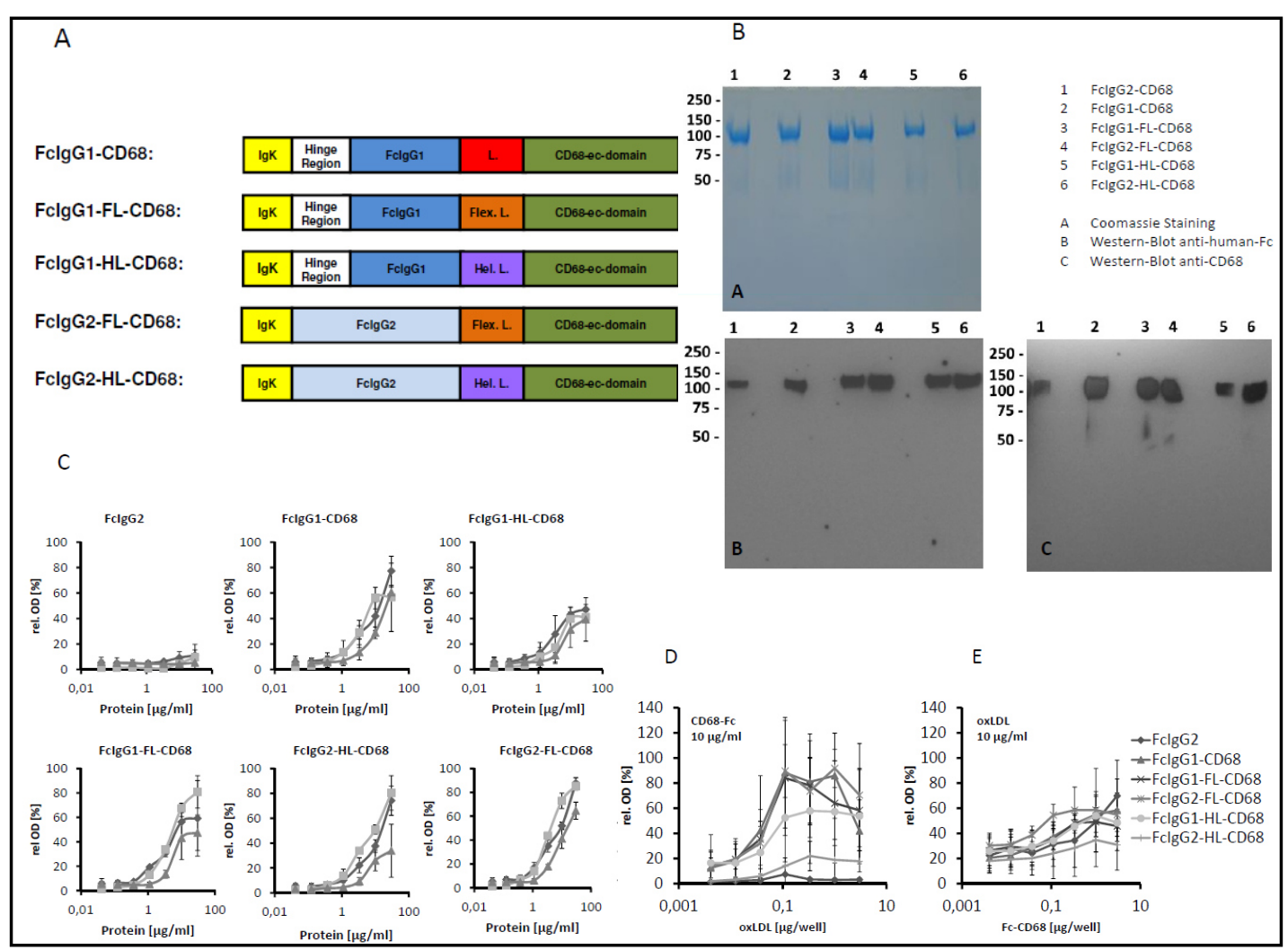

Fig. 1. (A) Schematic representation of the domain structure of Fc-CD68 fusion proteins. IgK: Ig Kappa leader sequence, hinge region, Fragments crystalizable (Fc) from human IgG1 or IgG2 were fused with the extracellular domain of CD68 using different linkers. L: short linker (GGR), Hel. L: linker with supposed rigid, helical conformation, Flex. L: linker with supposed flexible structure. (B) Coomassie-stained SDS-PAGE and Western-Blot analysis of the purified Fc-CD68 fusion proteins. A 4-20\% PAA gradient gel was used for all analysis. A: Coomassie staining. B: Western Blot with an anti human Fc antibody. C: Western-Blot with an anti CD68 antibody. (C) Binding ELISA with lipoproteins oxLDL, HDL and LDL (1 $\mu \mathrm{g} /$ well) immobilized on a 96-well Maxisorp plate. Dilution series of the different Fc-fusion proteins in the soluble phase were tested for binding. The Means \pm SEM of 4 independent experiments. (D) Binding ELISA with immobilized oxLDL. A dilution series of oxLDL (0.004-3 $\mu \mathrm{g} /$ well) was immobilized on a 96-well Maxisorp plate and binding of the different Fc-CD68 fusion proteins was tested using a fixed concentration in the soluble phase $(10 \mu \mathrm{g} /$ $\mathrm{ml}$ ). The Means \pm SEM of 4 independent experiments. (E) Binding ELISA with immobilized fusion proteins. A dilution series of the Fc-CD68 fusion proteins $(0,004-3 \mu \mathrm{g} / \mathrm{well})$ was immobilized. oxLDL $(10 \mu \mathrm{g} / \mathrm{ml})$ in the soluble phase was tested for binding. The Means \pm SEM of 4 independent experiments are shown. 


\section{Cellular Physiology Cell Physiol Biochem 2019;52;681-695

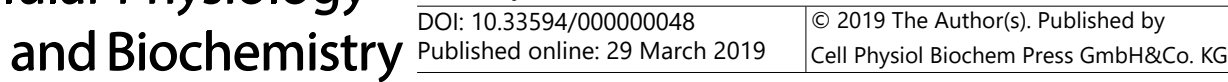 \\ Zeibig et al.: Platelet-Bound oxLDL Triggers Early Atherosclerosis}

Binding of different CD68-Fc proteins to oxLDL, LDL and HDL lipoproteins: high binding affinity to oxLDL with selectivity over $H D L$ but not $L D L$

The binding affinity of different CD68-Fc variants and the IgG control in soluble form to immobilized oxLDL, LDL and HDL in direct comparison was tested in an ELISA format assay. FcIgG1-CD68 and FcIgG2-FL-CD68 in the soluble phase displayed strongest, dose-dependent binding among all the fusion proteins, reaching saturation at around $1 \mu \mathrm{g} / \mathrm{ml}$ protein. Weakest binding was observed for FcIgG2-HL-CD68. The selectivity for oxLDL binding could be only shown in comparison to HDL. The difference to LDL binding was only weak. However, selectivity against HDL was found especially for FcIgG1-CD68 and FcIgG2-HL-CD68. FcIgG2 control protein showed almost no binding to immobilized lipoproteins (see Fig. 1c).

In addition to the fixed amount of immobilized oxLDL, HDL and LDL, a dilution series of oxLDL (3-0, $004 \mu \mathrm{g} /$ well) was coated to the assay plate and incubated with a fixed concentration of the fusion proteins in the soluble phase $(10 \mu \mathrm{g} / \mathrm{ml})$. The control FcIgG2 alone did not bind to oxLDL. However, FcIgG2-HL-CD68 only weakly bound to oxLDL, whereas FcIgG1-CD68, FcIgG1-FL-CD68 and FcIgG2-FL-CD68 showed active, sigmoidal dosedependent binding curves with oxLDL. Binding affinities ranged from 3.7 (FcIgG1-CD68) to 3.8 nM (FcIgG1-FL-CD68 and FcIgG2-FL-CD68) (Fig. 1d).

To directly compare the binding affinities of different immobilized Fc-CD68 fusion proteins to soluble oxLDL, parallel assays with a dilution series (3-0.004 $\mu \mathrm{g} / \mathrm{well}$ ) of the Fc-CD68 proteins coated to ELISA plates were measured with oxLDL in the soluble phase. Binding affinities (EC50 values) for oxLDL varied between 2.7 (FcIgG1-HL-CD68) to $4.7 \mathrm{nM}$ (FcIgG1-CD68) to oxLDL (Fig. 1e).

oxLDL concentrations in blood from patients with generalized atherosclerosis: reduction of oxLDL by specific $F c$-CD68 affinity resins

In serum samples from patients with generalized atherosclerosis and coronary artery disease oxLDL levels were $261.01 \pm 57.80 \mathrm{ng} / \mathrm{ml}$ with large variations from $103 \mathrm{ng} / \mathrm{ml}$ to 429 $\mathrm{ng} / \mathrm{ml}$ and therefore comparable to previously published reports. The manual of the ELISA kit reports 287 (18-2261) ng/ml as normal values in the German population also with a wide range of variation. We tested the binding properties of the different CD68 fusion proteins on native oxLDL from this patient blood with pull-down experiments using a specific affinity resin with the different Fc-CD68 proteins bound to protein G columns. After purging patient serum over the different protein G bead-coupled Fc-CD68 columns as well as columns with the IgG control protein, a slight decrease of oxLDL in the purified serum could be detected. Nevertheless, only FcIgG1-CD68 and FcIgG2-FL-CD68 showed a significant reduction of the oxLDL levels compared to the untreated serum. The FcIgG control also decreased serum oxLDL to some extend but did not reach the significance criteria (see Fig. 2).

Fig. 2. oxLDL-pull down experiments from blood of patients with severe atherosclerosis using protein G Sepharose-bound Fc-CD68 fusion proteins. Serum of atherosclerotic patients was applied to Fc-CD68 affinity resin collums and oxLDL content was measured before (serum) and after column application using a commerially available oxLDL/ MDA adduct ELISA. The relative values [in \%] compared to oxLDL levels in untreated serum as single data points and the Means \pm SEM of 7 independent experiments with different patient sera are shown. Each measurement was performed in duplicates. * indicated statistical significance of $\mathrm{p}<0.05$ compared to oxLDL in untreated serum.

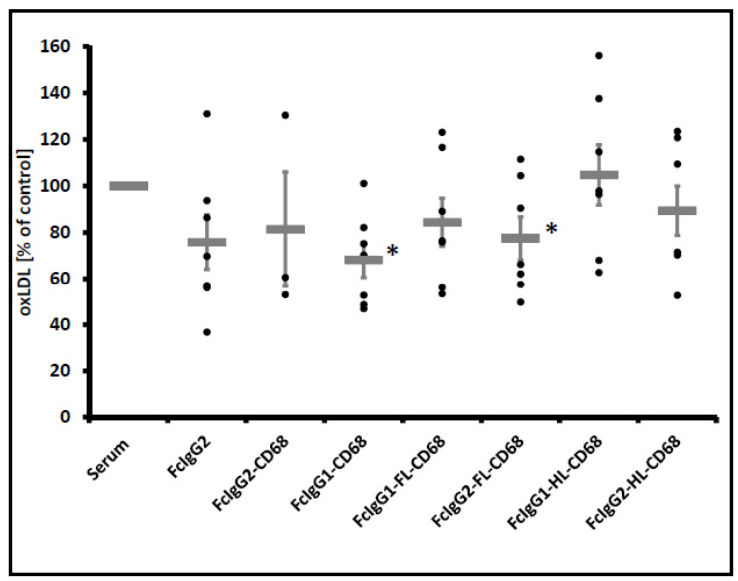




\section{Cellular Physiology Cell Physiol Biochem 2019;52;681-695 \begin{tabular}{ll|l} 
and Biochemistry & $\begin{array}{l}\text { DOl: 10.33594/000000048 } \\
\text { Published online: 29 March 2019 }\end{array}$ & $\begin{array}{l}\text { O 2019 The Author(s). Published by } \\
\text { Cell Physiol Biochem Press GmbH\&Co. KG }\end{array}$ \\
\cline { 2 - 3 } & Zerbir
\end{tabular}}

Effect of CD68-Fc fusion proteins on foam cell formation from human blood: reduction of foam cell formation by $F c-C D 68$

Co-cultures of CD14-positive monocytes and platelets from human blood developed foam cells after culturing cells for up to 8 days, in accordance to previous reports [9]. Representative images of a foam cell assay are shown in Fig. 3. Incubation of the co-cultures with different Fc-CD68 fusion proteins $(100 \mu \mathrm{g} / \mathrm{ml})$ reduced foam cell formation in human monocyte cultures. Some reduction of foam cell formation was also achieved with FcIgG2 which served as control protein. Very high concentrations of Simvastatin $(10 \mu \mathrm{mol} / \mathrm{l})$ also led to a significant reduction of the foam cell formation, whereas physiological concentrations $(0.01$ and $0.1 \mu \mathrm{mol} / \mathrm{l})$ did not display any effect on the foam cell formation. Physiological concentrations of Simvastatin are in the range from 1-15 nmol/L [10]. In contrast, the best inhibitory activity achieved by the CD68-HL-FcIgG1 and CD68-HL-FcIgG2 were in the concentrations also reached during pharmacokinetic measurement (see Fig. 3).

Effect of FcIgG2-FL-CD68 in LDLR $\% / A p o b e c^{-/}$mice: oxLDL was increased in atherosclerotic tissue and completely inhibited by $\mathrm{FC}$-CD 68 in tissue but not in peripheral blood

As the Fc-CD68- fusion protein with the best in vitro efficacy, we chose FcIgG2-FL-CD68 for animal studies. Twice weekly intraperitoneal injection with $10 \mathrm{mg} / \mathrm{kg}$ body weight for 4 weeks was well tolerated by all animals. Overall platelet count was increased in $L D L R^{\%}$ / Apobec $^{-1}$ mice with no effect on leukocytes (Fig 4a). In contrast to our hypothesis, oxLDL content in the plasma from Fc treated control $\mathrm{LDLR}^{-1} /$ Apobec $\%$ mice $(289.5 \pm 9.5 \mathrm{ng} / \mathrm{ml})$ was not altered compared to wildtype mice (oxLDL levels $296.5 \pm 19.5 \mathrm{pg} / \mathrm{ml}$ ). Moreover, in $L D L R^{\%} /$ Apobec $^{\%}$ mice treated with CD68-Fc fusion protein for 4 weeks, oxLDL levels in plasma were also unchanged both when compared to Fc treated mice and wildtype controls (296.0 \pm $13.3 \mathrm{pg} / \mathrm{ml}$ at the end of the treatment period). Moreover, in platelets and monocytes in the peripheral blood from $L D L R^{\%} /$ Apobec $^{\%}$ mice oxLDL concentration was significantly reduced compared to wild type mice (Fig. 4b). Similar observations were made in splenic monocytes

Fig. 3. (A) Representative images of a foam cell assay. A: Co-culture of thrombocytes and monocytes at $t=0$. B: In the presence of 10 $\mu \mathrm{M}$ Simvastatin after $96 \mathrm{~h}$ incubation only few differentiated cells (macrophages and foam cells) are visible. C: After $96 \mathrm{~h}$ of incubation without any additional substance macrophages and foam cells differentiate whereas platelet decrease in number. D: In higher magnification monocytes and foam cells can be clearly distinguished after $96 \mathrm{~h}$ of co-culture. Only few monocytes and platelets remained. Bars indicate the scale at different magnifications. (B) Inhibition of foam cell formation by Fc-CD68 proteins. The quantification of foam cells with co-culture of human monocytes and platelets was performed counting foam cells under the microscope. Mean values of 5 randomly selected, equally sized areas of the $10 \mathrm{~cm}$ culture dish are shown from. The Means \pm SEM of 4 independent experiments are shown.

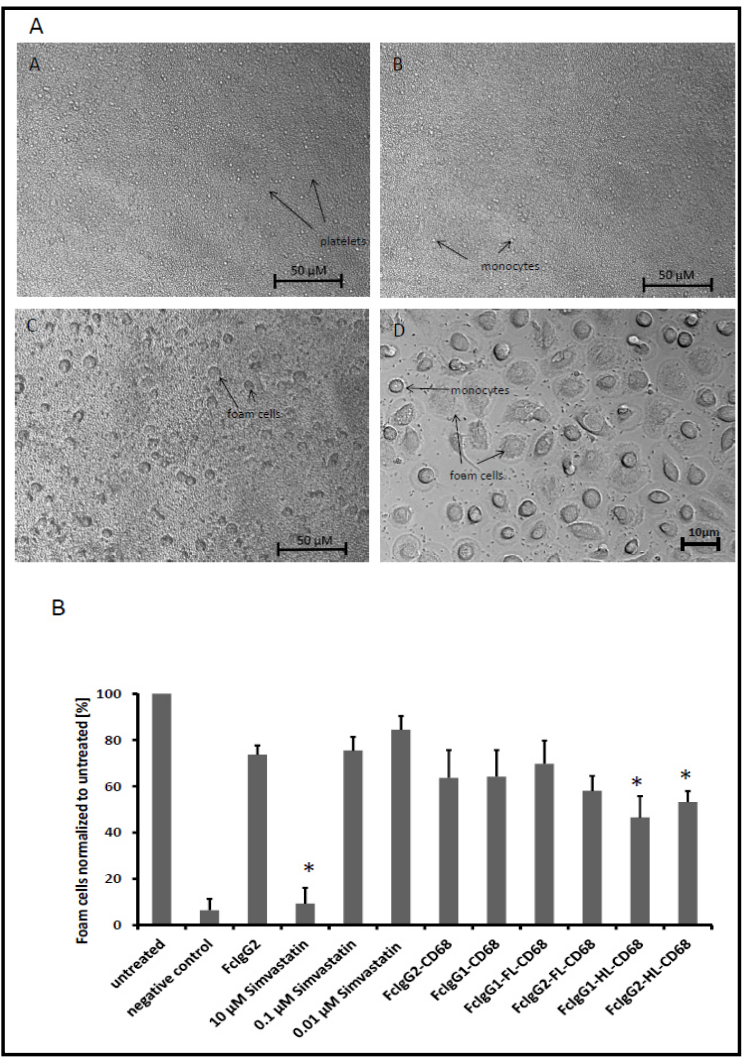



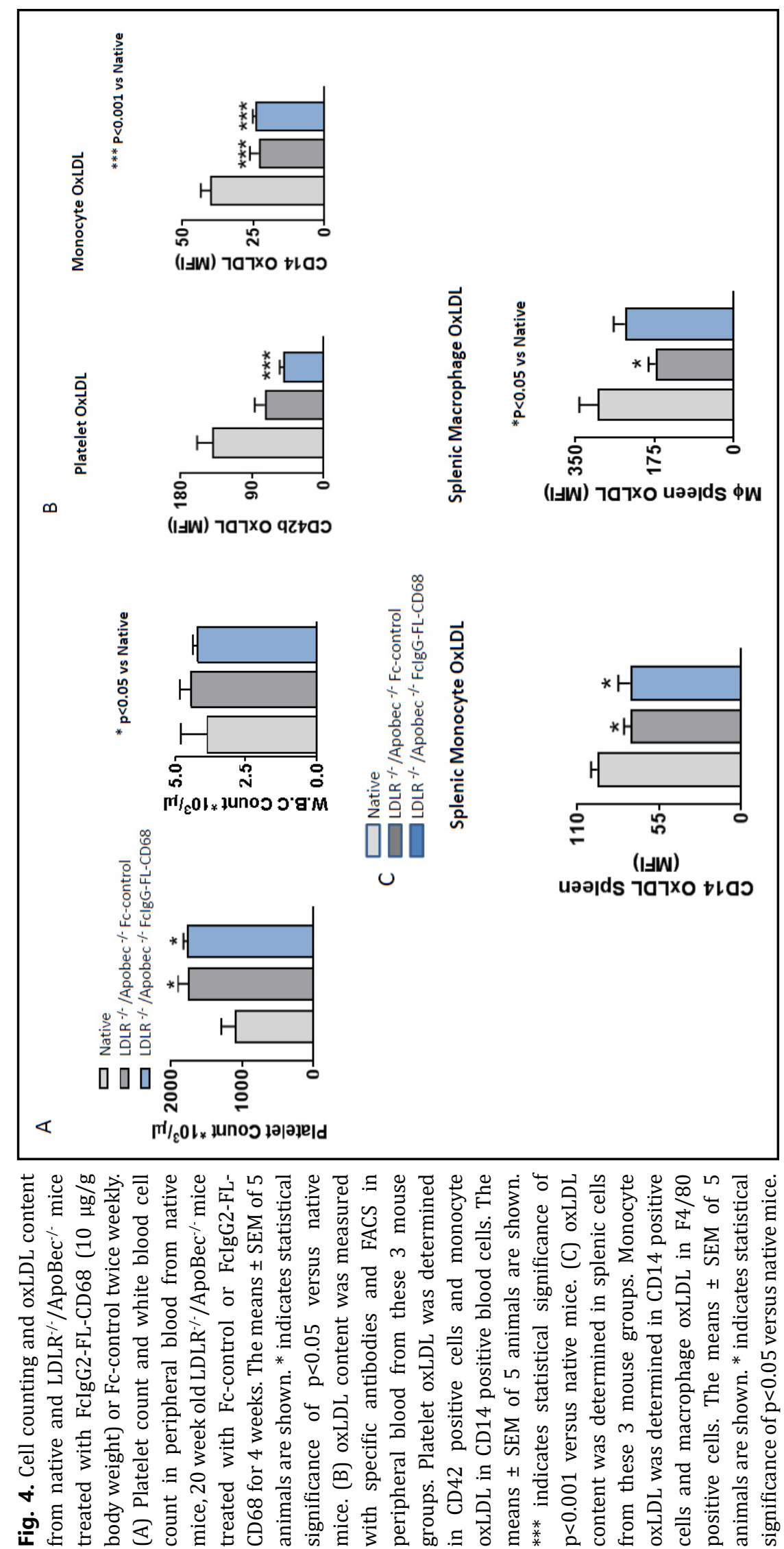


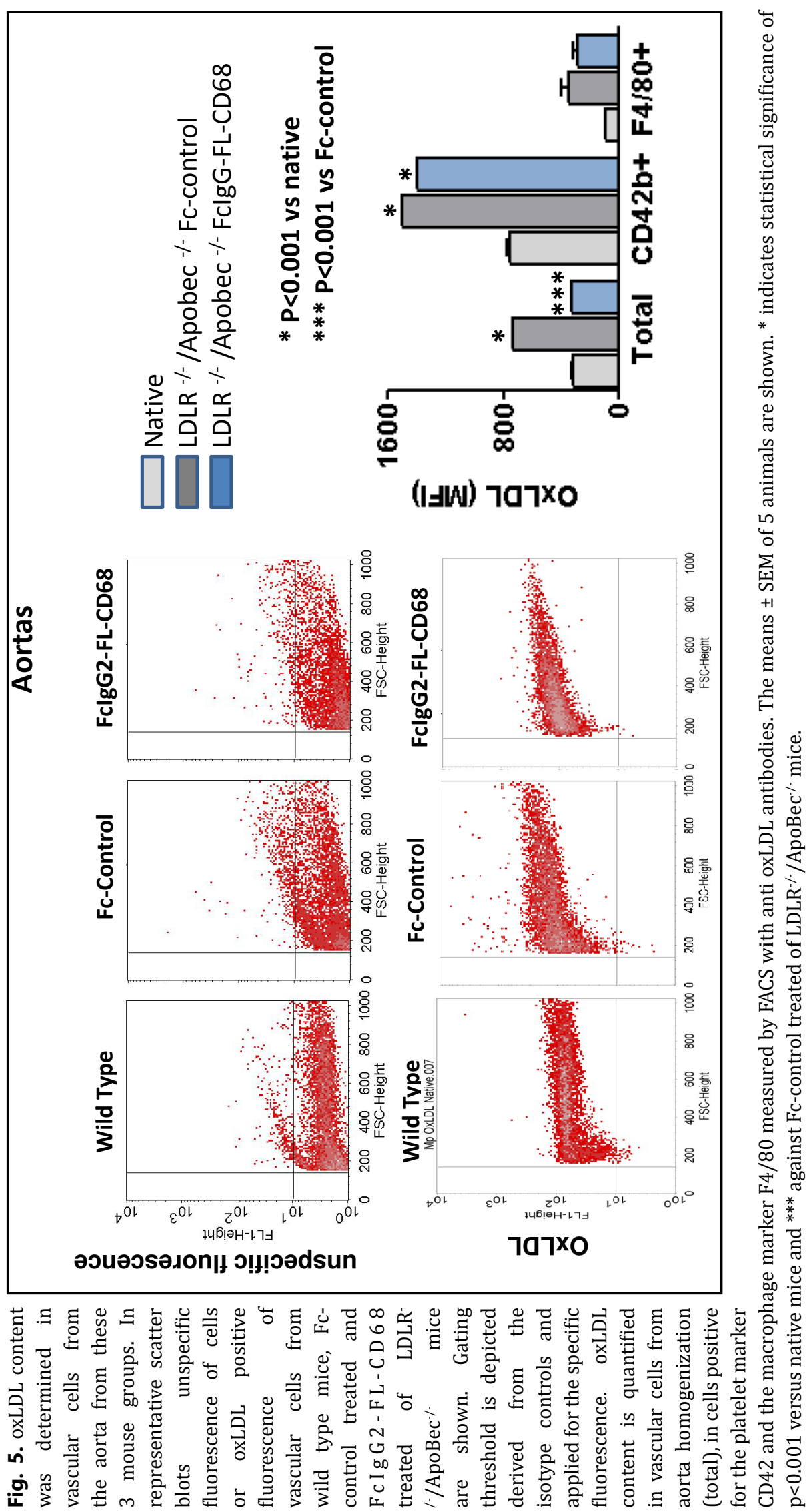




\section{Cellular Physiology Cell Physiol Biochem 2019;52;681-695 \\ \begin{tabular}{ll|l}
\cline { 3 - 3 } and Biochemistry $10.33594 / 000000048$ & P 2019 The Author(s). Published by \\
Published online: 29 March 2019 & Cell Physiol Biochem Press GmbH\&Co. KG
\end{tabular} \\ Zeibig et al.: Platelet-Bound oxLDL Triggers Early Atherosclerosis}

and macrophages, where we detected reduced oxLDL levels in FcIgG2-FL-CD68 and Fc-control treated $L D L R^{-\%} /$ Apobec $^{-1}$ groups as compared to untreated native mice (Fig. 4c). Treatment with FcIgG2-FL-CD68 had no effect on the oxLDL content of either peripheral or splenic monocytes or macrophages as compared to Fc-control. In contrast, oxLDL content in vascular cells from homogenates of the aortic wall was increased in $L D L R^{\%} /$ Apobec $^{\%}$ mice compared to wild type (Fig. 5). FcIgG2-FL-CD 68 treatment to $L D L R^{-\%} /$ Apobec $^{\%}$ mice reduced the oxLDL content in cells from the aortic wall as compared to Fc control. Total cell population from aortic homogenates showed this effect of FcIgG2-FL-CD68 treatment in decreasing vessel wall associated oxLDL content significantly and down to comparable values found in wild-type littermates (Fig. 5). In post-acquisition analysis of cells gated for the platelet specific marker CD42 oxLDL content was also significantly increased in $L D L R^{\%} /$ Apobec $^{\%}$ mice compared to wild-type. In F4/80-stained macrophages only a trend to increased oxLDL content compared to wild type mice was observed. Treatment with the FcIgG2FL-CD68 fusion protein had no influence on the oxLDL levels in theses platelets or macrophages isolated from the aortic wall.

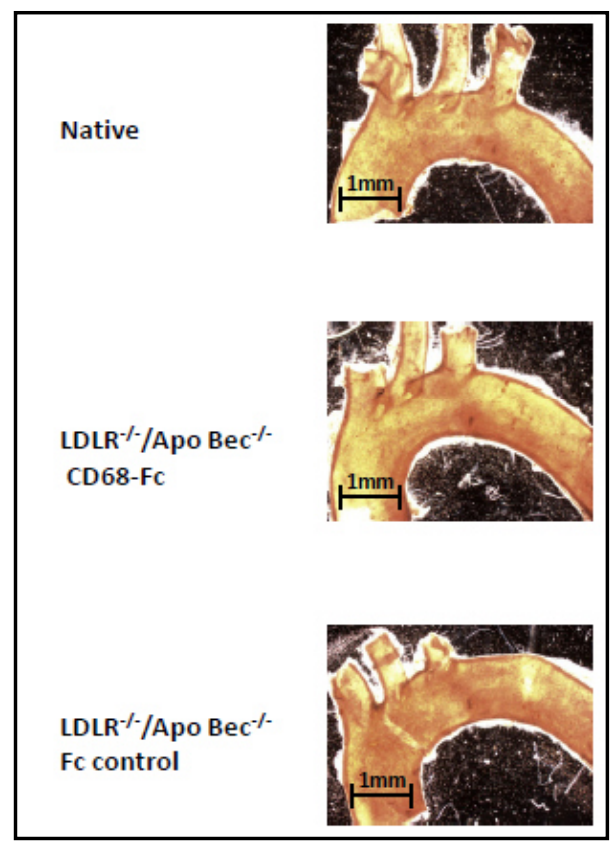

Fig. 6. Representative oil-red 0 staining of the aortic arch of native mice, $\mathrm{LDLR}^{-\%} /$ $\mathrm{ApoBec}^{-/}$after 4 weeks treatment with FcIgG2-FL-CD68 or with Fc-control. A slight beginning fatty streak formation is visible in the Fc control treated mice in accordance with an early form of atherosclerosis.

Vessel wall histology: early phase of atherosclerosis in 24 week old $L D L R^{-\%} /$ Apobec $\%$ mice

Oil red o staining of macroscopic preparations of aortas from these 24 week old $L D L R^{\%} /$ Apobec $^{\%}$ mice showed an early phase of atherosclerosis with almost no plaque formation due to the absence of high cholesterol challenge of the vessel wall under regular chow (Fig. 6).

\section{Discussion}

It was the aim of this study to investigate oxLDL in peripheral blood, the spleen and the vessel wall in early stages of atherosclerosis and to characterize novel, specific oxLDLmodifying drugs - the soluble form of the oxLDL scavenger receptor CD68- in this early phase of atheroprogression.

Surprisingly, early atherosclerosis in $L D L R^{\%} /$ Apobec $^{\%-}$ mice did not lead to increased blood levels of oxLDL in these atherosclerosis prone mice, whereas tissue levels of oxLDL in the aortic wall were markedly increased. In line with this observation, the oxLDL binding therapeutic protein FcIgG2-FL-CD68 was able to significantly block the oxLDL increase in the aortic wall, but not in peripheral blood cells including platelets and monocytes. We chose the $L D L R^{\%} /$ Apobec $^{-/}$mice without additional high cholesterol diet to study an in vivo model of atherosclerosis in the early phase of plaque development for several reasons: First, it has been shown that oxLDL-dependent foam cell formation is relevant in an early phase of atheroprogression [11]. Second, a previous study in ApoE-/- mice has shown that increases in the oxLDL level in peripheral blood are only transient and occur markedly earlier than the plaque formation in the vessel wall [12]. And third, in our previous study with Apo E -/- mice CD68-Fc had marked effects especially in the early progression of atherosclerosis 


\section{Cellular Physiology Cell Physiol Biochem 2019;52;681-695 \\ \begin{tabular}{ll|l} 
and Biochemistry $\begin{array}{l}\text { DOl: 10.33594/000000048 } \\
\text { Published online: 29 March 2019 }\end{array}$ & $\begin{array}{l}\text { O } 2019 \text { The Author(s). Published by } \\
\text { Cell Physiol Biochem Press GmbH\&Co. KG }\end{array}$ \\
\cline { 2 - 3 } & Zerbis
\end{tabular}}

[8]. In $L D L R^{\%} /$ Apobec $^{\%}$ atherosclerotic mice the plaque staining in the vessels therefore showed very weak plaque formation at the time of sacrifice confirming an early phase of atherosclerosis. oxLDL levels in serum, platelets and monocytes in peripheral blood and from splenic tissue were unchanged or rather decreased in $L D L R^{\%} /$ Apobec ${ }^{\%}$ mice compared to wild type. This stands in contrast to the existing theory of oxLDL levels as early markers of atherosclerosis in the peripheral blood. The literature of oxLDL levels in the blood is rather equivocal. Ehara and coworkers report an increase of the ratio of oxLDL normalized to total LDL protein only in the blood of patients with acute myocardial infarction but not with unstable angina or patients with stable coronary artery disease (CAD) [13]. Another group reported decreased oxLDL levels in patients with acute MI and no changes in patients with acute coronary syndrome or stable CAD [14]. Interestingly they reported acutely elevated LDL levels in acute MI which decreased during the post MI phase. As a result, the interpretation of ratios of oxLDL/LDL must be done with caution and could not mandatory reflect changes in the absolute oxLDL levels per se. There is one report about a population-based study where oxLDL blood levels were a strong predictor for future acute coronary syndrome in an otherwise healthy population [15]. As a conclusion, the picture of blood oxLDL as a marker is less clear than it seems at first sight especially in patients with stable coronary artery disease. In patients with acute coronary syndrome, oxLDL levels of circulating platelets were found to be elevated [16] and also in acute myocardial infarction with angiographic evidence of intracoronary thrombus [2]. Significant deposition of oxLDL was observed in platelet enriched areas which suggests that platelets are a vital depository of oxidized lipids in thrombus [2]. The situation in the vessel wall tissue however, seems clearer. Different groups reported increased oxLDL tissue levels and macrophage levels in atherosclerotic plaques. Also Ehara and colleagues found markedly increased absolute tissue oxLDL levels in atherectomy specimens from patients with unstable angina and coronary artery disease [13]. This could also be confirmed in the present study in $L D L R^{-\%} /$ Apobec $^{-/}$mice in the early phase of atherosclerosis. Therefore, the current concept of oxLDL as an early trigger for inflammation in the progress of atherosclerosis also applies to our model of $L D L R^{-/} /$Apobec $^{\%}$ mice even without high-fat diet for the investigation of early atherosclerosis. In contrast, increased plasma levels of oxLDL could not be determined in our study. Maybe we missed the rather narrow time window for such an increase in the peripheral blood. But the concept of leakage or release of oxLDL from unstable atherosclerotic plaques into the blood should be discussed based on these findings.

In general our data support the crucial role for platelets in early atherosclerosis. We found a clear increase in the overall platelet count in the $L D L R^{\%} /$ Apobec $^{\%}$ mice. However, the oxLDL content was not increased in platelets neither from peripheral blood nor in the spleen in $L D L R^{*} /$ Apobec $^{-/}$mice. Possibly also because of the increase of absolute platelet numbers in $L D L R^{\%} /$ Apobec $^{\%}$ mice leading to a dilution of oxLDL levels stored in more platelets. However, an almost doubling of the oxLDL level was found in cells isolated from the aortic wall positive for the platelet marker CD42b. We consider these cells either platelets which have invaded in the vessel wall or platelets that have been phagocytosed by vascular cells. This confirms earlier studies by Massberg et al. who found a crucial role for platelets in the peripheral blood as a trigger for atherosclerosis in intravital microscopy studies in ApoE-/- mice [17]. Additionally, tissue bound platelets contribute most to the increase in tissue oxLDL conctent and seem to be crucial for the early progression steps of atherosclerosis.

And is CD68 involved in the oxLDL metabolism of early atherosclerosis? Fc-CD68 contains the functional domain of a naturally occurring receptor on macrophages but, had no influence on plasma oxLDL levels after treatment of $L D L R^{\%} /$ Apobec $^{\%}$ mice in vivo. In contrast, Fc-CD68 proteins bound to oxLDL in vitro and were also able to decrease native oxLDL levels from human blood after specifically extracting native human, endogenous oxLDL from this blood by Fc-CD68 loaded protein G columns. Interestingly, in vivo treatment of $L D L R^{\%} /$ Apobec $^{\%}$ mice leads to a significant reduction of the tissue oxLDL level among cells in aortic homogenate. Therefore, we might add another argument for a significant role of CD68 as an oxLDL scavenger receptor. Different candidates of oxLDL scavengers have 


\section{Cellular Physiology Cell Physiol Biochem 2019;52;681-695 \\ \begin{tabular}{ll|l}
\cline { 3 - 3 } and Biochemistry $10.33594 / 000000048$ & P 2019 The Author(s). Published by \\
Published online: 29 March 2019 & Cell Physiol Biochem Press GmbH\&Co. KG
\end{tabular} \\ Zeibig et al.: Platelet-Bound oxLDL Triggers Early Atherosclerosis}

been debated controversially $[18,19]$. Also about CD68 or the mouse analogue macrosialin, conflicting findings have been reported $[5,20]$. However, we could previously show that CD68 binds oxLDL with 10 nmolar affinity [9] and could confirm these results with different recombinant CD68 proteins in the current manuscript. As a shortcoming our in vitro experiments with Fc-CD68 in the soluble phase did not distinguish between the oxidized and non-oxidized LDL immobilized by coating to the assay plate, whereas the proteins showed a preference over HDL. Taken together especially looking at the effect of native oxLDL from patients' blood, we consider the Fc-CD68 fusion proteins active for the binding against both (artificially) copper-oxidized oxLDL but also endogenous oxLDL from patients with advanced atherosclerosis. Especially, the ex vivo findings of reduction in foam cell formation speak for a relevant influence on the oxLDL and foam cell formation. Thus, Fc-CD68 is functional for oxLDL binding and scavenging in vitro and with human blood ex vivo and leads to a decrease of tissue oxLDL in vivo in mice exhibiting early signs of atherosclerosis. Although CD68 is a vital scavenger receptor on monocytes and macrophages for oxLDL uptake, the soluble form of the receptor Fc-CD68 did not have any significant effect on the plasma levels of oxLDL therefore failed to show a significant impact on peripheral or splenic monocytes and/or macrophages. The effect on peripheral platelets and CD42 positive vascular cells from the aorta was weak and did not reach the significance level as compared to Fc-control but was significantly different from native untreated mice. In contrast the effect of CD68-Fc was clear cut in the overall cell population from the aortic vessel wall.

But how does it bind and decrease the oxLDL tissue levels? The large Fc fusion protein will not diffuse into the vessel wall but is confined to the intra-vascular space. This was confirmed in a previous study with in vivo application of radiolabeled Fc-CD68 fusion proteins. Accumulation in plaques from ApoE -/- mice was detected in PET/CT images in vivo. Further immune-histological investigations confirmed the localization of the Fc-CD68 fusion protein on the surface of the atherosclerotic plaques [21]. More previous studies also confirmed that Fc-CD68 fusion proteins bind to atherosclerotic plaques from atherosclerosis-prone ApoE -/- mice and from patients with coronary artery disease ex vivo [9]. Rather oxLDL, which is able to migrate through vessels could be scavenged by the soluble Fc-CD68 fusion protein and be transported away from the vessel wall or early developing atherosclerotic plaque. This is in line with our previous study [8] where CD68-Fc treatment reduced plaque progression markedly in early phases of atherosclerosis and prevented plaque rupture and stabilized plaque especially in advanced forms of atherosclerosis. Interestingly, T-cells and macrophages were reduced by over $50 \%$ in these older mice by CD68-Fc treatment. Combining the two studies I would dare to speculate that this might be causal for the decreased inflammation and cellularity finally leading to a decrease of plaque extension and more importantly to plaque rupture, which has been shown in our previous study [8].

Even if we saw increased oxLDL levels in tissue platelets, the decoy CD68-Fc fusion protein showed no cell-specific effect on oxLDL levels in tissue platelets and only a trend for reduction in peripheral platelets. The cell type involved and the further mechanisms leading to this decrease of tissue oxLDL remains to be elucidated by future investigations. As a limitation of our study, the missing effect of CD68-Fc fusion proteins on the oxLDL levels as compared to Fc control especially in platelets could also be a consequence of the Fc-control, which showed some effect e.g. on the oxLDL levels from patients with CAD in this study and also on foam cell formation in a previous study [9]. Especially in platelets there was always a trend for CD68-Fc to reduce oxLDL in peripheral platelets and vessel wall cells positive for platelet markers with respect to wild type mice. The lack of significance of CD68-Fc treatment compared to the Fc-controls could therefore be a consequence of an effect of Fc alone on oxLDL levels.

Other approaches to bind and block oxLDL in vivo have been done with specific antibodies targeting a specific epitope of oxLDL (a MDA-modified apoB-100 peptide) [7]. In the same genetic mouse model as we used, treatment with anti-oxLDL antibodies reduced atherosclerotic plaques by $50 \%$ and macrophage vessel wall content by $38 \%$. Despite these encouraging results, further development of the antibody BI-204 in humans with advanced, 


\section{Cellular Physiology Cell Physiol Biochem 2019;52;681-695

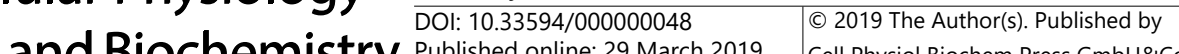 \\ \begin{tabular}{l|ll} 
Published online: 29 March 2019 Cell Physiol Biochem Press GmbH\&Co. KG \\
\hline
\end{tabular} \\ Zeibig et al.: Platelet-Bound oxLDL Triggers Early Atherosclerosis}

stable atherosclerotic disease failed. Patients with carotid or aortic plaques were assessed. Due to the lack of efficacy in plaque inflammation measured by PET, the company only communicated the negative outcome of the GLACIER study. Unfortunately, the initially promised detailed results of this interesting approach have never been published. Maybe the negative results were due to the unsuitable study protocol with advanced stage of atherosclerosis in the patients investigated rather than an ineffective drug candidate. Finally, novel oxLDL scavenging treatment with CD68-Fc seems to be especially suitable in early atherosclerosis which has implications on the design of potential patient studies but offers an attractive concept for early prophylaxis to prevent deleterious clinical events in patients if treatment is initiated to the right timepoint early in disease progression.

\section{Acknowledgements}

This project was funded by the Deutsche Forschungsgemeinschaft (DFG, German Research Foundation) Klinische Forschungsgruppe-KFO-274 "Platelets - Molecular Mechanisms and Translational Implications" (Project number 190538538) and TRP 240 "Plateles - Molecular, cellular and systemic functions in health and disease" (Project number 374031971). We also acknowledge the support by Open Access Publishing Fund of University of Tübingen.

\section{Disclosure Statement}

G. Münch, M. Ungerer and M. Gawaz are co-founders and shareholders of advanceCOR. The other authors have nothing to disclose.

\section{References}

1 Hansson GK: Inflammation, atherosclerosis, and coronary artery disease. N Engl J Med 2005;352:16851695.

2 Chatterjee M, Rath D, Schlotterbeck J, Rheinländer J, Walker-Allgaier B, Zdanyte M, Müller I, Borst O, Geisler T, Schäffer TE, Lämmerhofer M, Gawaz M: Regulation of oxidized platelet lipidome: implications for coronary artery disease. Eur Heart J 2017;38:1993-2005.

- 3 Chatterjee M, von Ungern-Sternberg SN, Seizer P, Schlegel F, Büttcher M, Sindhu NA, Müller S, Mack A, Gawaz M: Platelet-derived CXCL12 regulates monocyte function, survival, differentiation into macrophages and foam cells through differential involvement of CXCR4-CXCR7. Cell Death Dis 2015;6:e1989.

- 4 Graeves DR, Gordon S: The macrophage scavenger receptor at 30 years of age: current knowledge and future challenges. J Lipid Res 2009;50:S282-286.

- 5 Ramprasad MP, Terpstra V, Kondratenko N, Quehenberger O, Steinberg D: Cell surface expression of mouse macrosialin and human CD68 and their role as macrophage receptors for oxidized low density lipoprotein. Proc Natl Acad Sci USA 1996;93:14833-14838.

- 6 Tsimikas S, Miyanohara A, Harvingsten K, Merki E, Shaw PX, Chou MY, Pattison J, Torzewski M, Sollors J, Friedmann T, Lai NC, Hammond HK, Getz GS, Reardon CA, Li AC, Banka CL, Witztum JL: Human oxidationspecific antibodies reduce foam cell formation and atherosclerosis progression. J Am Coll Cardiol 2011;58:1715-1727.

7 Schiopu A, Frendeus B, Jansson B, Söderberg I, Ljungcratz I, Araya Z, Shah P K, Carlson R, Nilson J, Fredrikson GN: Recombinant antibodies to an oxidized low-density lipoprotein epitope induced rapid regression of atherosclerosis in Apobec-1 -/- / low-density lipoprotein receptor -/- mice. J Am Coll Cardiol 2007;50:2313-2318.

8 Zeibig S, Li Z, Wagner S, Holthoff HP, Ungerer M, Bültmann A, Uhland K, Vogelmann J, Simmet T, Gawaz M, Münch G: Effect of the oxLDL binding protein Fc-CD68 on plaque extension and vulnerability in atherosclerosis. Circ Res 2011;108:695-703. 


\section{Cellular Physiology Cell Physiol Biochem 2019;52;681-695

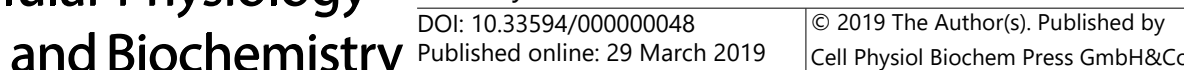 \\ Zeibig et al.: Platelet-Bound oxLDL Triggers Early Atherosclerosis}

- 9 Daub K, Siegel-Axel D, Schönberger T, Leder C, Seizer P, Müller K, Schaller M, Penz S, Menzel D, Büchele B, Bültmann A, Münch G, Lindemann S, Simmet T, Gawaz M: Inhibition of foam cell formation using a soluble CD68-Fc fusion protein. J Mol Med 2010;88:909-920.

- 10 Björkhem-Bergman L, Lindh JL, Bergman P: What is a relevant statin concentration in cell experiments claiming pleiotropic effects? Br J Clinc Pharmacol 2011;72:164-165.

- 11 Chen C, Khismatullin DB: Oxidized Low-Density Lipoprotein Contributes to Atherogenesis via Co-activation of Macrophages and Mast Cells. PLoS One 2015;10:e0123088.

- 12 Kato R, Mori C, Kitazato K, Arata S, Obama T, Mori M, Takahashi K, Aiuchi T, Takano T, Itabe H: Transient increase in plasma oxidized LDL during the progression of atherosclerosis in Apolipoprotein E knockout mice. ATVB 2009;29:33-39.

- 13 Ehara S, Ueda M, Naruko T, Haze K, Itoh A, Otsuka M, Komatsu R, Matsuo T, Itabe H, Takano T, Tsakamoto Y, Yoshiyama M, Takeuchi K, Yoshikawa J, Becker A: Elevated levels of oxidized low density lipoprotein show a positive relationship with the severity of acute coronary syndromes. Circulation 2001;103:1955-1960.

14 Tsimikas S, Bergmark C, Beyer RW, Patel R, Pattison J, Miller E, Juliano J, Witztum JL: Temporal increases in plasma markers of oxidized low-density lipoprotein strongly reflect the presence of acute coronary syndrome. J Am Coll Cardiol 2003;41:360-370.

- 15 Meisinger C, Baumert J, Khuseyinova N, Loewel H, Koenig W: Plasma oxidized low-density lipoprotein, a strong predictor for acute coronary heart disease events in apparently healthy, middle-aged men from the general population. Circulation 2005;112:651-657.

- 16 Stellos K, Sauter R, Fahrleitner M, Grimm J, Stakos D, Emschermann F, Panagiota V, Gnerlich S, Perk A, Schönberger T, Bigalke B, Langer HF, Gawaz M: Binding of oxidized low-density lipoprotein on circulating platelets is increased in patients with acute coronary syndrome and induces platelet adhesion to vascular wall in vivo- Brief Report. Arterioscl Thromb Vasc Biol 2012;32:2017-2020.

- 17 Massberg S, Brand K, Grüner S, Page S, Müller E, Müller I, Bergmeier W, Richter T, Lorenz M, Konrad I, Nieswandt B, Gawaz M: A critical role of platelet adhesion in the initiation of atherosclerotic lesion formation. J Exp Med 2002;196:887-896.

18 Kuchibhotla S, Vanegas D, Kennedy DJ, Guy E, Nimako G, Morton RE, Febbraio M: Absence of CD36 protects against atherosclerosis in ApoE knock-out mice with no additional protection provided by absence of scavenger receptor A I/II. Cardiovasc Res 2008;78:185-196.

19 Moore KJ, Kunjathoor VV, Koehn SL, Manning JJ, Tseng AA, Silver JM, McKee M, Freeman MW: Loss of receptor mediated lipid uptake via scavenger receptor A or CD36 pathways does not ameliorate atherosclerosis in hyperlipidemic mice. J Clin Invest 2005;115:2192-2201.

- 20 de Beer MC, Zhao Z, Webb NR, van der Westhuyzen DR, de Villiers WJ: Lack of a direct role for macrosialin in oxidized LDL metabolism. J Lipid Res 2003;44:674-685.

- 21 Bigalke B, Phinikaridou A, Andia ME, Cooper MS, Schuster A, Wurster T, Onthank D, Münch G, Blower P, Gawaz M, Nagel E, Botnar RM: PET/CT and MR imaging biomarker of lipid-rich plaques using [64Cu]labeled scavenger receptor (CD68-Fc). Int J Cardiol 2014;177:287-291. 